\title{
The Social Position of Doctoral Candidates within the Academic Field: Comparative Considerations Regarding Doctoral Program Attrition in Germany and the USA
}

\begin{abstract}
Summary: During the ongoing period of transformation of the German doctoral education from the individual master-apprentice model to more structured PhD programs, US-American PhD programs have served as a model for many of the newly established programs. One of the political aims of restructuring doctoral education in Germany within the last decade is the reduction of attrition rates.

However, it remains unknown whether differences exist between the attrition rates and what the causes of non-completion are. Therefore, the objective of this paper is to discuss the need of a comparative empirical study to understand doctoral program attrition in both countries.

This article first examines the organization of doctoral education in Germany and the USA with reference to doctoral program attrition. Secondly, it explains Bourdieu's concept of the scientific field and the social position of doctoral students. Finally, it suggests taking a closer look at the position of doctoral students, their amount of capital and possible actions as implications for further research.

Key words: Doctoral Students, Doctoral Program Attrition, Theory of the Academic Field, Comparative Study
\end{abstract}

Резюме (Аня Франц: Социальная позиция докторанток в научном пространстве: сравнительные наблюдения относительно прекращения обучения в аспирантуре с последующей защитой диссертации в Германии и США): В ходе длительных реформ в системе высшего образования Германии американские программы защиты диссертации служат примером для трансформации немецкой системы защиты диссертации от индивидуальной защиты к более сильным структурированным формам защиты. Кроме всего прочего, таким образом, преследуется политическая цель, сократить количество аспирантов, прекративших обучение. Однако, до сих пор неясно, насколько велики и какие различия имеются в этом отношении. Кроме того, неизвестны причины прекращения обучения в аспирантуре.

Соответственно цель данной статьи состоит в обосновании необходимости проведения сравнительного исследования, состоящего в изучении причин прекращения обучения 8 аспирантуре в обеих странах. На переднем плане представлен обзор системы защиты диссертации в Германии и США; проводится сравнение результатов прежних исследований относительно прекращения обучения в аспирантуре с последующей защитой диссертации. После этого автор статьи конщентрирует внимание на конщепции научного пространства по Пьеру Бурдьё и на структурных признаках социальной позиции докторанток в этом пространстве. $B$ заключении предлагается уделить внимание сравнительному эмпирическому исследованию причин прекращения обучения в аспирантуре с социальной позиции докторанток. Для этого необходимо подробнее рассмотреть наделение их финансовыми средствами и связанные с этим возможности действия.

Ключевые слова: аспиранты, прекращения обучения в аспирантуре с последующей защитой диссертации, отказ от защиты диссертации, теория научного пространства, сравнительное исследование

Zusammenfassung (Anja Franz: Die soziale Position von Doktoranden im wissenschaftlichen Feld: Vergleichende Betrachtungen zu Abbrüchen von Promotionsvorhaben in Deutschland und den USA): Im Zuge 
der andauernden Reformen im deutschen Hochschulraum dienen die US-amerikanischen Promotionsprogramme als Vorbild für die Transformation des deutschen Promotionswesens von der Individualpromotion hin zu stärker strukturierten Promotionsformen. Damit wird unter anderem das politische Ziel verfolgt, die Abbruchraten zu verringern. Dennoch ist bislang unklar, inwiefern und welche Unterschiede in Bezug auf die Abbruchraten bestehen. Außerdem sind die Ursachen für Abbrüche unbekannt.

Entsprechend ist das Ziel dieses Artikels, die Notwendigkeit einer vergleichenden Untersuchung von Abbrüchen von Promotionsvorhaben in beiden Ländern zu begründen. Im Vordergrund steht zunächst ein Überblick über das deutsche und das amerikanische Promotionswesen; bisherige Forschungsergebnisse zu Abbrüchen von Promotionsvorhaben werden im Vergleich vorgestellt. Danach fokussiert der Artikel auf das Konzept des wissenschaftlichen Feldes nach Pierre Bourdieu sowie auf die strukturellen Merkmale der sozialen Position von DoktorandInnen in diesem Feld. Abschließend wird vorgeschlagen, für eine vergleichende empirische Untersuchung von Abbrüchen von Promotionsvorhaben der sozialen Position der DoktorandInnen Beachtung zu schenken. Hierfür sollten ihre Ausstattung mit relevantem Kapital sowie die damit in Verbindung stehenden Handlungsmöglichkeiten näher in den Blick genommen werden.

Schlüsselwörter: Promovierende, Abbruch von Promotionsvorhaben, Promotionsabbruch, Theorie des wissenschaftlichen Feldes, vergleichende Studie

\section{Introduction}

Doctoral education and training forms the first phase of any young researcher's career and is therefore a major priority for universities globally. However, doctoral students, deemed the most academically successful students within the higher education system in Germany, also face severe problems in attempting to complete their $\mathrm{PhD}$ degree. Traditionally, achieving a $\mathrm{PhD}$ in Germany is individualised: The research proposals of candidates have to be accepted by an academic supervisor. Candidates then carry out the planned $\mathrm{PhD}$ work that typically does not require the completion of preparatory coursework or examinations within a PhD program. However, the traditional German PhD model has come under pressure. Since doctoral education and training has been included in the Bologna Process, it is becoming the norm for European higher education policy to embed doctoral education and training strongly in their institutional structures. During this ongoing period of transformation and innovation, US-American PhD programs have served as a model for many of the newly established doctoral programs in Germany.

One of the political aims of restructuring doctoral education and training in Germany is the reduction of attrition rates, while the transformation of the traditional doctoral education into doctoral education programs is seen as a panacea from many education policy makers. Therefore, the objective of this paper is to discuss the need of a comparative empirical study to understand the course of doctoral program attrition in Germany and the USA. This article first examines the organization of doctoral education in Germany and the USA with reference to doctoral program attrition in both countries. An overview of the institutional structure of each doctoral education and training system may help to understand the context of doctoral program attrition. Secondly, it explains Bourdieu's concept of the scientific field and its implications (as a base) for further research on doctoral program attrition.

\section{Doctoral Education and Training in Germany and the USA}

The number of doctoral degrees awarded in Germany and the USA significantly increased according to the OECD within the past decade, with about 24,000 in Germany or 46,000 degrees in the USA awarded in 1999 and 27,000 and 73,000 respectively in 2011 (Hauss et al., 2012). Of the relevant age cohort in 20072.3 percent in Germany and 1.5 percent in the USA graduated at doctoral level (OECD, 2010). Approximately 0.45 percent of women and 0.95 percent of men in the overall working age 
population between the age of twenty-five and sixty-four were doctorate holders in Germany in 2009; the same figure for the USA is slightly higher for women ( 0.55 percent) and slightly lower for men (0.8 percent) (OECD, 2013). In summary, Germany and the USA are those countries worldwide in which the highest numbers of doctoral degrees are awarded and both are among those countries with the highest proportion of the population holding a doctoral degree.

In Germany, the sixteen federal states own the greatest amount of responsibility for education in general. The majority of German universities are public, while only few private institutions exist. Regarding doctoral education, the German universities are required to enact detailed regulations according to the state law on higher education. The requirements within those regulations vary between universities and even schools (Kehm, 2008). All of the more than 100 universities in the country award doctoral degrees. Within the states of Bavaria, Berlin and Baden-Wuerttemberg most of the doctoral degrees have been granted in 2010 at the rate of 1.1 doctoral degrees per supervising professor (Statistisches Bundesamt, 2012a).

The US American university system is also decentralized; the federal government does not regulate those institutions. Public universities are usually administered by the states as part of the state university system. Many private universities are funded by endowments, beneficence, investments and student fees. Doctoral degrees can also solely be granted by universities. Although more than 400 institutions actually award doctoral degrees, doctoral education is mainly concentrated at the few major research universities which award more than half of the doctoral degrees in the USA. Doctoral education is under the sovereignty of the departments of those doctoral-granting (Nerad, 2008).

In the next chapter the general basic structure of doctoral education, admission processes, financing, completion of the dissertation and formal presentation as well as the average time to obtaining the degree and age upon completion will be addressed. The paper then focuses on ongoing reforms in both countries to understand recent changes in doctoral education.

\section{Traditions and Ongoing Reforms of Doctoral Education in Germany}

The doctoral degree in Germany is usually an academic degree that follows research-oriented master's education. The traditional model of doctoral education and training (so called master-apprentice model) is based on a personal relationship between the doctoral candidate and the supervisor (so called "doctor-mother" or "-father"). Apart from possible colloquia organized by the supervising professor, the PhD project does not take place within formal doctoral programs or graduate schools at university level as it does in the USA. The doctorate is planned personally and achieved through individual study and research work. This system offers a lot of flexibility since there are usually no deadlines and no compulsory curriculum but it requires a great dedication at the same time.

As there is no federal structure for applications to doctoral education in Germany, the candidates have to apply directly with a prepared research proposal to the professor of their choice. The professor then chooses the appropriate candidate, takes over supervision and finally acts as the first reviewer for the thesis. Apart from that, every university/department has its own set of admission requirements. As a general rule a well-graded Master's degree is required for entry to doctoral education. Exceptionally well-qualified applicants may be admitted on fast-track with only a Bachelor's degree, in which case extra examinations will usually be necessary.

Doctoral candidates are often temporarily employed as part-time junior researchers at universities (50 percent of a full-time position). They are usually considered academic staff, not students (though they sometimes hold a student status as well). Holding such a position typically means that doctoral 
candidates are also involved in teaching, research and administrative work at their supervisor's chair or research group. The supervisor usually acts not only as an employer but also as the first reviewer of the dissertation and main examiner of the oral defense, which implies a high personal dependency (Kehm, 2008). Other less frequent forms of funding a PhD in Germany are scholarships and grants (provided by the German states, political or elite foundations) or through working part-time and doing the PhD work avocationally (Wissenschaftsrat, 1995). Commonly, a doctoral candidate in Germany pays no tuition fees, but an administrative fee per semester ranging between 70 and 270 Euros depending on the university. Usually two formal requirements must be met for obtaining a doctorate in Germany: the completion of a doctoral thesis (dissertation) and an oral examination that includes a lecture or presentation followed by a discussion. The average time to degree varies between four and six years. The average age upon completion is 33 (Statistisches Bundesamt, 2014).

More than two-thirds of all doctoral candidates are still trained traditionally as described above while less than ten percent participate in a structured doctoral program (Statistisches Bundesamt, 2012b). While the traditional PhD can be structured freely to suit the individual research project, the $\mathrm{PhD}$ work in structural programs has to fit within an existing doctoral program. Those programs include compulsory attendance of lectures and seminars (covering topics such scientific methods, theory, writing and presentation techniques) and regular exams. The duration is generally limited to three years. The doctoral candidates are considered students and work steadily within a group of doctoral students while being supervised by a group of academic staff. However, one professor serves as their first supervisor and reviewer.

Meeting the needs of the Bologna Process (Bologna Declaration, 1999; Berlin Communiqué, 2003; Bergen Communiqué, 2005), universities now have to shift their focus to innovative structured programs. Within the last fifteen years, the overall number of doctoral programs offering structured doctoral education such as in the USA has increased steadily. Nevertheless, the idea of structured doctoral education in Germany is not as new as it seems. The German Council of Science and Humanities already recommended in the early 1990s more structured doctoral education programs. This was followed by the establishment of the first graduate schools by the German Science Foundation (DFG) almost twenty-five years ago. Today, the number of graduate schools and structured PhD programs is rising steadily, with over 200 graduate schools being funded by the DFG and 39 graduate schools being funded solely by the so called Excellence Initiative of the German Federal Government and the state governments, as two examples.

\section{Traditions and Ongoing Reforms of Doctoral Education in the USA}

In the USA doctoral education is part of graduate education. Graduate education as specialized advanced study can result in either a Master's degree or a doctoral degree. A doctoral degree can either be academic (such as $\mathrm{PhD}$ ) or professional (such as EdD). There is a great variety between various doctoral programs but some standard structures are generally consistent throughout the USA. Doctoral education typically starts with a few semesters of full-time advanced classes, which are usually done in small groups. After usually three to four semesters students have to pass written and/or oral exams before they begin to work for a period of at least one year on their independent research project on a highly specialized topic and write their dissertation. They are considered doctoral students throughout the whole period of doctoral education.

Doctoral programs in the USA have a highly selective process of admission. An average of only one quarter of all applicants is accepted. In general, the requirements for attending doctoral education are a Bachelor's degree (four-year course of study, a certain grade point average), a passed national 
graduate entrance exam, several letters of recommendations of previous professors and a statement of purpose (Nerad, 2008).

Doctoral students in the USA pay high tuition fees compared to Germany, which have risen up to US\$28,000-40,000 per year and even higher at elite private universities. There are some governmental and private foundations who fund doctoral students. Commonly, the graduate schools at universities also have their own graduate student fellowship programs. However, many doctoral students hold a working position at their department as teaching or research assistants for one up to four years to partially fund their doctoral education. Once the research work and the written dissertation are complete, the doctoral student earns the doctoral degree after defending the dissertation to a committee of three or more professors who are also part of the doctoral program the student participates in. The average time to degree ranges at present between five to nine years and the median age of completion was also 33 years in 2003 (Nerad, 2008).

Within the last decade and longer, doctoral education in the US has had to cope with further reductions in financing with just a few exceptions, such as life sciences or research focusing on national security aspects, which receive more state and governmental funding. Some major criticism of doctoral education in the USA includes the narrow training of doctoral students that focuses only on their special research topic, the lack of important professional skills such as the ability to work in a team or to properly teach at university level, and the long duration to completion of a degree. This criticism has led to the discussion of an increased federal role in graduate education. The National Science Foundation and the Council of Graduate Schools founded various national and local initiatives to further improve doctoral education. The goals are, for example, to provide independent funding for doctoral students through the doctoral program and not the advisor, to encourage multidisciplinary and interdisciplinary approaches and to reorganize the program structure in order to train the students in a wide range of professional skills so they will meet the demands of the labor market outside academia (Nerad, 2008).

In conclusion, the traditional model of doctoral education in Germany and the way doctoral candidates are trained in the USA have not much in common in terms of educational process, type of work, financing or status as student or researcher. The new concepts of structured doctoral education in Germany are strongly influenced by the US American traditional system, but there are considerable differences. For example, doctoral students in Germany have already obtained a research degree and then immediately start in a graduate school with their doctoral work. Possible coursework is usually complementary instead of required before the start of research. However, in both countries large numbers of doctoral degrees are awarded; the average time to degree in both models is comparable and the median age of newly awarded PhD holders is around 33. In the next chapter attention is given to attrition rates and possible reasons for departing from doctoral education.

\section{Attrition from Doctoral Education in Germany and the USA: A Literature Review}

One of the most discussed issues regarding doctoral education in both countries today is doctoral student attrition because of various critical issues:

Attrition generates opportunity costs for universities in financial aid and faculty time, and for students in foregone earnings and delayed entry into alternative career tracks that better fit their talents and interests, as well as psychic costs for students whose previous academic achievement was exemplary. (Smallwood, 2004, p. A10). 
Even if lower attrition rates suggest benefits for the institution and the individual in terms of both resources in time and money, there is a lack of research on attrition in doctoral education in Germany. On the contrary, until now research has been focused almost solely on successful doctoral students. No federal statistical data in Germany exists on doctoral program attrition. The "Bundesnachwuchsbericht", a study concerning the situation of doctoral students and faculty members at early career stages, suggests an estimated rate of attrition of between 30 and close to 70 percent based on a small regional dataset. That means: In the worst possible case only one in three candidates is successfully completing the doctoral degree (Burkhardt, 2008). Another study suggests, based on a wider database of more than one university, lower numbers with an overall attrition rate of 17 percent with a slightly higher rate for women than for men (19 vs. 16 percent). The highest number of doctoral candidates who leave their programs was found in psychology, pedagogy, social sciences and engineering with almost one quarter in each field (Fabian, Rehn, Brandt, \& Briedis, 2013). The widely divergent figures are probably due to varying data and measuring methods. It can be reasonably assumed that the numbers of doctoral students leaving their doctoral project are somewhere in between the stated numbers.

Supervision is considered as one of the main problems of doctoral education in Germany:

Personal dependence on the supervisor, insufficient contact with the supervisor, or exploitation by the supervisor has been identified as typical problem areas in this respect (Kehm, 2008, p. 27).

Other reasons mentioned for attrition are the additional workload while working as part-time faculty members and in some cases professional reorientation (Fabian et al., 2013). Up to now, there is nothing known about similarities and differences in attrition between the traditional model of doctoral education in Germany and more structured programs.

Thinking about leaving a doctoral project or dropping out of doctoral education seems to be quite common in Germany. Different studies show that between one quarter (Berning \& Falk, 2006; Falkenhagen, 2008) and almost half (Abels, 2002) of the doctoral candidates had thought at least once throughout their doctoral work about leaving. Thinking about leaving relates to various sociodemographic, psychological, economic and institutional factors (Korff, 2015). Women are more likely to think about leaving than men (Berning \& Falk, 2006; Abels, 2002). The financial situation of the candidates is similarily important. Berning and Falk (2006) show that thinking about leaving is a little more probable while doing doctoral work individually, outside of a structured program. However, problems with supervision and additional workload are the main institutional reasons for thoughts about leaving (Berning \& Falk, 2006). The study of Korff (2015) suggests that individual characteristics of doctoral students contribute to the explanation of the differences regarding thoughts of leaving but institutional attributes like supervision, coursework, overall workload and group dynamics among doctoral students play the most significant role within structured programs. However, at present, there is no knowledge of significant correlations between thinking and actually leaving doctoral education.

In conclusion, the numbers of doctoral candidates in Germany as well as the rate of attrition is unknown and can only be estimated. Besides nothing is known about the determination of the relation between causes and effects. Moreover, a comparison of attrition rates between the traditional German model and more structured programs is simply not possible due to lack of obtained data. In fact it is not known whether participants of structured programs are more successful and if so, why. 
In the USA, continuously high attrition rates between 40 and 50 percent from doctoral programs have been found during the last decades (Bowen \& Rudenstine, 1992; Sowell, 2008; Lovitts, 2001). Just like in Germany, these numbers vary considerably between the disciplines, departments and also universities (Golde, 2005; Lovitts, 2001). However, in summary almost every second student enrolled in a doctoral education program fails to earn the obtained degree and there is still little evidence that those numbers may be subject to changes (Halse \& Malfoy, 2010; Willis \& Carmichael, 2011). Overall, it has to be noted that

the most academically capable, most academically successful, most stringently evaluated, and the most carefully selected students in the entire higher education system - doctoral students are the least likely to complete their chosen academic goals (Golde, 2000, p. 199).

Diverse studies suggest that attrition is more common in social sciences and humanities than in natural sciences (Sowell, 2008; Golde, 2005; Nettles \& Millett, 2006). Looking closer at socio-demographic factors, the groups of women and of students of color seem to be more likely to be at risk of dropping out (Bowen \& Rudenstine, 1992; Nerad \& Miller, 1997; Nettles \& Millett, 2006). The economic background seems to be important as well. Those who have less funding are found more likely at risk of leaving their program (Attiyeh, 1999). Additionally, Lovitts (2001) states, that those students are socially less integrated with the faculty and with their student peers.

Attrition rates in doctoral education in both countries are high. This seems applicable regardless of whether doctoral education is structured or not. Causes and reasons of leaving respectively thoughts about leaving in both countries appear to be more similar than expected.

Looking at the high numbers and the lack of research at least for the German case it could be questioned if attrition is intentional within the academic field or not:

Attrition rates of 50 percent or more would be a scandal in any professional school, but seem to be accepted in doctoral education as part of the natural order. (Breneman, 1977, p.18).

If attrition is part of a "natural order" in academia, it is supported by those who are actors in the field or, at least, tolerate it. However, no matter if attrition is truly supported or just tolerated, it is necessary to understand doctoral program attrition in both countries, particularly if one of the aims of the described structural reforms in Germany based on the US American model is to reduce those rates. Therefore, a closer look needs to be taken at the structure of the academic field and the position of doctoral students within that field. Pierre Bourdieu $(1975,2004)$ suggests a concept of the academic field which is helpful to understand the "natural academic order" and gives some implications for research on doctoral student attrition.

\section{Theoretical Assumptions about Doctoral Student Attrition: The Concept of the Academic Field of Pierre Bourdieu}

\section{Bourdieu's Concept of the Academic Field}

Pierre Bourdieu $(1975,2004)$ uses the concept of social fields to describe the social world. A social field is understood as a social space which is structured by connected social relations between agents and their positions. The idea is, that cultural production and its products are constituted in terms of a number of processes and social realities. Cultural products and producers are located within a 
space of positions and position-takings that constitutes a set of relations. A social field is characterized by its own rules, hierarchic schemes of power and domination and special legitimate opinions and objects of interests. The social world consists of a variation of different social fields. Those fields are considered relatively autonomous from external forces, while the agents follow its own specific distinctive logic. The less external resources a field requires and the higher the price of entry is, the more anonymous it is at the same time (Bourdieu, 2004). Since social agents have the belief ("illusio"), that it is worth investing in the objects of interest and that the rules of the social field are reasonable and rightful, Bourdieu describes the social field as social game or competition which is valuable playing to its participants. The objective of the participants is to accumulate capital in that special social game, while the type of the capital of interest differs between the various social fields, while capital means anything that is valuable in the field. The more capital of interest social agents accumulate, the higher their social position and the more powerful they are within the field. However, in modern societies and their social fields, capital is unequally distributed between social agents and causes social hierarchies. Depending on the amount of relevant capital agents have different chances to become successful within the field. Those differences regarding social positions constitute the social structure of a social field. Those within the field understand the strategies and powers and they know how to behave in the field. That understanding feels natural to them (Bourdieu \& Wacquant, 1992). According to Bourdieu, one of the fields in modern societies is the academic field, which is

a social field like any other, with its distribution of power and its monopolies, its struggles and strategies, interests and profits, but it is a field in which all these invariants take on specific forms" (Bourdieu, 1975, p. 19).

The logic of the academic field is based on the aim to discover the universal truth which is within the field believed to be a truth found via scientific methods and measurements such as testable explanations or predictions (Bourdieu, 2004).

In the academic field or competition the social agents struggle for authority over the academic truth which means "the sense of a particular agent's socially recognized capacity to speak and act legitimately (i.e. in an authorized and authoritative way) in scientific matters" (Bourdieu, 1975, p. 19).

The more academic authority social agents have, the greater their influence is on the definition of scientific objects of interest such as scientific knowledge, findings or methods. The most valuable capital in the academic field is called "academic" or "scientific" capital. The acquisition of academic capital is only possible within the academic field as it means recognition or acknowledgment through peer review by other academic agents or competitors. Social mechanisms of valuation are e.g. the publication of scientific papers, amount and quality of citation, academic presentations at reputable conferences, academic awards, tenure or the membership in academic societies. In addition, a doctoral student's acceptance by a certain professor, studying at a certain university or the receipt of scholarships are mechanisms of recognition within the academic world, in this case, for students. Academic achievements or an excellent research performance is therefore a social product. Interestingly, the importance of recognition by other social agents within the field means that the competitors are at the same time consumers and senders: "In the scientific field, where recognition of "competence" and "authority" cannot be forced without the scrutiny of other competitor producers, credit comes from symbolically appropriating others' work, incorporating into one's own work and going beyond it." (Lenoir, 1997, p. 54). The position of social agents varies depending on their capacity and success to accumulate academic capital in the past. This special capital is also unequally distributed between social agents and therefore causing social hierarchies. That is, the most powerful social agents and their academic practice is the criterion for the production of scientific knowledge and defines current regulations for the measurement of scientific truth (Lenoir, 1997). 


\section{The Position of Doctoral Students within the Academic Field}

The cost of entry into the academic field is considered high because e.g. certified evidence of training in higher education is needed. A successful scientist follows a certain career path and the doctorate is the most important but also terminal official degree on the academic career track and demonstrates the candidates' ability to complete a substantial body of original research, although many PhD holders do not end up working in academia.

Following Bourdieu, the doctorate must be understood as an institutionalized form of acknowledgment, meaning academic capital, through peer review within the field. Doctoral students are newcomers or beginners and have to adapt to the rules of the field. They have some cultural capital such as education certificates but they usually lack social capital within academia as they commonly have only been in contact with their undergrad teachers. They also lack economic capital as they normally earn much less than others within the academic system. Accordingly they have a relatively weak and dependent position within the social hierarchy of academia. Robert Merton $(1968,1988)$ has shown in his research on Nobel Prize winners that there is a strong relation between accumulated academic capital and the accumulation of further relevant capital called the "Matthew Effect" or "accumulated advantage". That means powerful agents within the academic field receive a much larger amount of recognition for comparable research work than weaker agents like doctoral students or candidates who are forced to produce even more scientific knowledge for true acknowledgement. At the same time, doctoral students are highly dependent on a professor or supervisor but also on other powerful social agents within the field like journal editors who have sufficient academic capital and determine the rules for the production of scientific knowledge. In summary, doctoral students can be considered rather weak within the social field of academia which impedes doctoral research work generally and the completion of the PhD degree specifically.

Following the theoretical approach of Bourdieu, talent, intellectual ability and hard work are important but plenty of other field-related aspects have also to be taken into account for doctoral achievements. To better understand doctoral program attrition it would be useful to subsequently take a closer look at the position of doctoral candidates, their amount of relevant capital and their related possible actions within the academic field in comparison between Germany and the USA.

\section{Summary and Conclusions}

This paper examined doctoral education in Germany and the USA and took a closer look at doctoral program attrition in both countries. On the basis of those reflections the aim was to shed some light on Bourdieu's concept of the scientific field and its implications for further research on doctoral program attrition.

Both the US and Germany belong to those countries worldwide in which the highest numbers of doctoral degrees are awarded. The traditional model of doctoral education in Germany and doctoral programs in the USA have not much in common in terms of educational process, type of work, financing or status. However, the newly structured doctoral education programs in Germany are strongly influenced by the US American concepts and the restructuring is politically seen as a universal remedy for all problems considered to be within the traditional German doctoral education. Nevertheless, when comparing the two, in both countries large numbers of doctoral degrees are awarded, the average time to degree in both models is quite long and the median age of completion is around age 33. Attrition rates in both countries are high and this seems to apply regardless of whether doctoral education is structured or not. Estimated causes and reasons of leaving appear to be more similar than expected. Therefore, attrition could be considered as part of the natural order of academia. It would 
seem important to question the academic field and its social structure and mechanisms while researching doctoral program attrition. Pierre Bourdieu's $(1975,2004)$ concept of the academic field might be helpful as it suggests the field as a hierarchic social structure centered on the production of scientific knowledge and the accumulation of acknowledgement and recognition. Assuming academia as being such a field consisting of hierarchical social positions of field agents with different social power it would not be artificial to consider doctoral students holding a social position as well. However, the position of doctoral students or candidates can be considered as weak within the scientific competition as they did not receive much scientific capital earlier and they do not own much other capital, such as economic capital, either.

In conclusion, the hypothesis of this paper is the success of doctoral students apart from talent, scientific abilities or workload, depending primarily on various field-related aspects. An approach for research on attrition focusing solely on the individual students' intellectual or social ability is too narrow because it ignores the mechanisms of the academic field of work.

Hence, this paper suggests taking a closer look at the social position of doctoral candidates, their amount of relevant capital and their possible actions within the academic field and thus compare Germany and the USA. In order to gain a deeper knowledge of the social position of doctoral candidates it is necessary to analyze the multidimensional relations regarding these candidates within the academic field and how their position might change throughout their doctoral education. To understand the phenomenon of a doctoral attrition process qualitative case-focused research is needed to investigate the reasons and paths of making a dropout decision. The findings will lead to implications for restructuring German doctoral education based on the US-American model.

\section{References}

Attiyeh, G. M. (1999): Determinants of persistence of graduate students in Ph. D. programs. In: ETS Research Report Series, 1999(1), i-43.

Bergen Communiqué (2005): The European Higher Education Area: Achieving the Goals. Conference of European Ministers Responsible for Higher Education in 45 countries. Bergen, Norway.

Berlin Communiqué (2003): Realising the European Higher Education Area. Conference of Ministers responsible for Higher Education in 33 European Countries. Berlin, Germany.

Bologna Declaration (1999): Towards the European Higher Education Area. Conference of Ministers responsible for Higher Education in 29 European countries. Bologna, Italy.

Bourdieu, P. (1975): The specificity of the scientific field and the social conditions of the progress of reason. In: Social Science Information, 14(6), 19-47.

Bourdieu, P. (2004): Science of science and reflexivity. Cambridge: Polity Press.

Bowen, W. G., \& Rudenstine, N. L. (1992): In: Pursuit of the Phd. Princeton, New Jersey: Princeton University Press.

Breneman, D. W., Jamison, D. T., \& Radner, R. (1976): The Ph. D. production process. In: Education as an Industry, NBER, 1-52.

Burkhardt, A. (2008): Wagnis Wissenschaft. Akademische Karrierewege und das Fördersystem in Deutschland. Leipzig: Akademische Verlagsanstalt.

Sowell, R. (2008): PhD completion and attrition: Analysis of baseline data. Washington DC: Council of Graduate Schools, 1-23.

Fabian, G., Rehn, T., Brandt, G., \& Briedis, K. (2013): Karriere mit Hochschulabschluss. In: HIS: Forum Hochschule (Vol. 10, 2013).

Golde, C. M. (2000): Should I stay or should I go? Student descriptions of the doctoral attrition process. In: The Review of Higher Education, 23(2), 199-227. 
Golde, C. M. (2005): The role of the department and discipline in doctoral student attrition: Lessons from four departments. In: The Journal of Higher Education, 76(6), 669-700.

Halse, C., \& Malfroy, J. (2010): Retheorizing doctoral supervision as professional work. In: Studies in Higher Education, 35(1), 79-92.

Hauss, K., Kaulisch, M., Zinnbauer, M., Tesch, J., Fräßdorf, A., Hinze, S., \& Hornbostel, S. (2012): Promovierende im Profil: Wege, Strukturen und Rahmenbedingungen von Promotionen in Deutschland; Ergebnisse aus dem ProFile-Promovierendenpanel. Berlin: iFQ.

Kehm, B. (2008): Germany. In: Nerad, M., \& Heggelund, M.: Toward a global PhD?: forces and forms in doctoral education worldwide. University of Washington Press, 19-35.

Lenoir, T. (1997): Instituting science: The cultural production of scientific disciplines. Stanford, California: Stanford University Press.

Lovitts, B. E. (2001): Leaving the ivory tower: The causes and consequences of departure from doctoral study. Lanham, Maryland: Rowman \& Littlefield.

Merton, R. K. (1968): The Matthew effect in science. In: Science, 159(3810), 56-63.

Merton, R. K. (1988). The Matthew effect in science, II: Cumulative advantage and the symbolism of intellectual property. In: Isis, 606-623.

Nerad, M. (2008): United States of America. In: Nerad, M., \& Heggelund, M. (2011). Toward a global PhD?: forces and forms in doctoral education worldwide. University of Washington Press, 278300.

Nerad, M., \& Miller, D. S. (1996): Increasing student retention in graduate and professional programs. In: New directions for institutional research, 1996(92), 61-76.

Nerad, M., \& Miller, D. S. (1997): The institution cares: Berkeley's efforts to support dissertation writing in the humanities and social sciences. In: New Directions for Higher Education, 1997(99), 75 90.

Nettles, M. T., \& Millett, C. M. (2006): Three magic letters: Getting to Ph. D. Baltimore, Maryland: JHU Press.

OECD (2010): Measuring Innovation: A New Perspective. Paris: OECD.

OECD (2013): Science, Technology and Industry Scoreboard: Innovation for Growth. Paris: OECD.

Statistisches Bundesamt (2012a): Hochschule auf einen Blick 2012. Wiesbaden: Statistisches Bundesamt.

Statistisches Bundesamt (2012b): Promovierende in Deutschland 2010. Wiesbaden: Statistisches Bundesamt.

Statistisches Bundesamt (2014): Bildung und Kultur. Prüfungen an Hochschulen. Fachserie 11, Reihe 4.2. Wiesbaden: Statistisches Bundesamt.

Willis, B., \& Carmichael, K. D. (2011): The lived experience of late-stage doctoral student attrition in counselor education. In: The Qualitative Report, 16(1), 192-207.

Wissenschaftsrat (1995): Empfehlungen zur Neustrukturierung der Doktorandenausbildung und förderung. Saarbrücken: Geschäftsstelle Wissenschaftsrat.

\section{About the Author}

Anja Franz: MA in Sociology and Education, Lecturer and Researcher at Otto-von-Guericke University Magdeburg, Institute of Education Science (Germany). Contact: anja.franz@ovgu.de 